\title{
Historical Overview of Leprosy Control in Cuba
}

\author{
Enrique Beldarraín-Chaple MD PhD
}

\begin{abstract}
INTRODUCTION Leprosy, an infectious disease caused by $\mathrm{Myco-}$ bacterium leprae, affects the nervous system, skin, internal organs, extremities and mucous membranes. Biological, social and environmental factors influence its occurrence and transmission. The first effective treatments appeared in 1930 with the development of dapsone, a sulfone. The main components of a control and elimination strategy are early case detection and timely administration of multidrug therapy.
\end{abstract}

OBJECTIVES Review the history of leprosy control in Cuba, emphasizing particularly results of the National Leprosy Control Program, its modifications and influence on leprosy control.

EVIDENCE ACQUISITION The historiological method was applied using document review, complemented by interviews with experts on leprosy and its control. Archived documents, medical records, disease prevalence censuses conducted since 1942, and incidence and prevalence statistics for 1960-2015 from the Ministry of Public Health's National Statistics Division were reviewed. Reports and scientific literature published on the Program and the history of leprosy in Cuba were also reviewed.

DEVELOPMENT Leprosy has been documented in Cuba since 1613. In 1938, the Leprosy Foundation was created with ten dispensaries nationwide for diagnosis and treatment. The first National Leprosy Control

\section{INTRODUCTION}

Leprosy or Hansen disease is an infectious disease caused by Mycobacterium leprae, an acid-fast bacillus. It affects the nervous system, skin, internal organs, extremities and mucosae.[1] For centuries, leprosy was not considered a disease in some cultures, but rather a curse or divine punishment.[2] It is thought to have originated in India, but has been described in China and the Middle East since antiquity.[2] Ancient texts describe the suffering it caused its victims, both clinically and socially. In 1510, Spanish colonization and the African slave trade introduced leprosy into the Americas.[2]

According to WHO, 213,899 new cases were notified globally in 2014 , and there were 175,554 patients under treatment for leprosy at the end of that year, for a point prevalence of 0.25 per 10,000 population.[3]

Leprosy is transmitted from person to person through the upper respiratory tract and skin, without requiring intermediate vectors or nonhuman reservoirs (although $M$. leprae has been isolated from the plantar pads of nine-banded armadillos).[4] Nevertheless it is not highly contagious, and, when treated properly, transmissibility is null. Patients who receive no or inadequate treatment constitute a source of contagion.[5] Leprosy occurrence and transmission are influenced by a combination of biological host factors and socioenvironmental factors. Biological factors include genetics and aging. The main source of transmission is cohabitation with undiagnosed or untreated patients who have enough bacterial load for contagion, and who expel
Program was established in 1962, implemented in 1963 and revised five times. In 1972, leper colonies were closed and treatment became ambulatory. In 1977, rifampicin was introduced. In 1988, the Program instituted controlled, decentralized, community-based multidrug treatment and established the criteria for considering a patient cured. In 2003, it included actions aimed at early diagnosis and prophylactic treatment of contacts. Since 2008, it prioritizes actions directed toward the population at risk, maintaining five-year followup with dermatological and neurological examination. Primary health care carries out diagnostic and treatment activities. The lowest leprosy incidence of 1.6 per 100,000 population was achieved in 2006. Since 2002, prevalence has remained steady at 0.2 per 10,000 population. Leprosy ceased to be considered a public health problem in Cuba as of 1993. In 1990-2015, 1.6\% of new leprosy patients were aged $<15$ years. At present, late diagnosis of cases exceeds $20 \%$, which leads to a high percentage of grade 2 disability in such patients. Spontaneous physician visits by already symptomatic patients surpassed $70 \%$ of cases diagnosed in $2010-2015$.

CONCLUSIONS Actions undertaken after initial detection of leprosy in Cuba failed to control it. Effective control began in 1963, with the implementation of the National Leprosy Control Program, whose systematic actions have had an impact on trends in leprosy, reflected in WHO's 1993 declaration that leprosy was no longer a public health problem in Cuba.

KEYWORDS Leprosy, Mycobacterium leprae, history of medicine, epidemiology, communicable disease control, Cuba the bacteria through mucous membranes in their upper respiratory tracts.[4] Among socioenvironmental factors, overcrowding and poor nutrition favor disease occurrence and transmission. Poverty and lack of education are associated with low risk perception and behaviors that increase transmission risk. Migration to or from high-risk areas with leprogenic foci also affects transmission.[6]

Leprosy can be classified by clinical criteria (based on the number of skin lesions and affected areas) and by presence or absence of $M$. leprae in skin smears, but skin smears are not available in all settings. The WHO Expert Committee on Leprosy recommends an operational classification: paucibacillary single-lesion leprosy (one lesion), paucibacillary (2-5 cutaneous lesions) and multibacillary leprosy ( $>5$ lesions). When skin smears are unavailable, cases are classified clinically as paucibacillary ( $\leq 5$ lesions) or multibacillary. When smears are available, even a single positive lesion is sufficient to treat as multibacillary with multidrug therapy (MDT).[7]

The first effective treatments against leprosy appeared in the late 1930s, with the introduction of dapsone (a sulfone) and its derivatives. However, in the 1960s dapsone-resistant strains of M. leprae appeared,[8] and in the 1980s, breakthrough therapies based on MDT were introduced.[1,8,9] Today, leprosy is a curable disease. Treatment should last between six months and two years (depending on the disease form) and is based on administration of dapsone with other drugs such as rifampicin and clofazimine (WHO-recommended MDT).[3,10,11] 


\section{Review Article}

The aim of leprosy control is to interrupt transmission. WHO's recommended strategy for leprosy control and elimination[11] includes three components: (1) early detection of cases; (2) establishing priorities based on stratification, monitoring and systematic assessment of epidemiological and operational indicators; and (3) timely administration of MDT to all patients. Early detection is facilitated by geographical stratification of cases based on epidemiological and operational indicators. Epidemiological indicators include percentage of new cases detected in the general population and in those aged $<15$ years, percentage of early diagnoses, proportion of new cases that are multibacillary, percentage of patients with grade 2 disability among new cases and leprosy prevalence. Operational indicators include percentage of multibacillary patients subjected to bacteriological followup in the year, percentage of contacts investigated, percentage of visits to leprosy patients and contacts, percentage of smear microscopies with positive diagnosis, and number of smear microscopies performed on multibacillary cases.[3,11] WHO considers leprosy eliminated as a public health problem when prevalence is $<1$ per 10,000 population.

Leprosy has been reported in Cuba since 1613,[12] but its real systematic control began with the National Leprosy Control Program (PNCL), which was established in 1962 and began operations in 1963. The objectives of this paper are to provide a historical overview of leprosy and its control in Cuba, and to analyze PNCL's results, modifications and influence on leprosy control.

\section{EVIDENCE ACQUISITION}

The historiological method was applied,[13] with document review for data acquisition. Archived documents, medical records, disease prevalence censuses conducted since 1942, and leprosy morbidity and mortality statistics for 1960-2015 from the National Statistics Office of the Ministry of Public Health (MINSAP) were reviewed, along with scientific publications and reports on PNCL and leprosy trends in Cuba. Recognized Cuban experts in leprosy management and control were interviewed.

Operational definitions Early diagnosis is carried out before symptoms appear, or within 11 months after their appearance, when there are still no signs of disability. Late diagnosis occurs after 11 months of symptom onset or when the patient already has some disability.

Disability is classified as grades 0,1 and 2, and applied separately to extremities and eyes. For extremities, grade 0 corresponds to patients with no functional impairment; grade 1 refers to loss of sensitivity (anesthesia) in hands or feet with no visible deformity, and grade 2 to cases with both anesthesia and complications such as trophic ulcers, claw deformities and bone resorption in extremities. For eye lesions, grade 0 is no leprosy-related vision loss; grade 1, some vision impairment, but not severe (vision 6/60 or better; patients can count fingers from 2 to 6 meters away); and grade 2 involves severe vision loss.[14]

Disease detection is classified as spontaneous when a patient with symptoms spontaneously consults a physician; by risk group, if leprosy is detected by case finding in a risk group; or by contact, if the case is found through contact tracing.
Data analysis General incidence and prevalence data for 1960 2015 were used for analysis of PNCL results. Prior to 1993, information about prevalent cases was obtained from patient census data.[15] Population sizes for estimating prevalence (per 10,000 population) were derived by the usual procedure of using population projections based on the closest previous population census and annual population growth rate.[16] Time series differed among indicators analyzed, beginning in different years because of limitations in data availability. Analysis was restricted to years with available information: for overall incidence and prevalence, 1960-2015; for incidence in the pediatric population, 1990-2015; for late diagnoses, 2006-2015; for new cases with grade 2 disability, 2005-2015; and for new cases by source of detection, 2010-2015. Although this lack of uniformity in length could be considered a limitation, analysis is restricted to available statistics, without temporal extrapolations, which rules out missing data as a source of bias.

\section{DEVELOPMENT}

Leprosy in Cuba before 1959 Leprosy did not exist in preColumbian America. It arrived with the Spanish and was later augmented with forced immigration of African slaves.[15,17] Although there is little historical documentation on leprosy in Cuba, it has been present since the beginning of European colonization; [2,15] Cuba's first cases were reported in Havana in 1613, according to a historical review published in 1963. [15] Table 1 summarizes (by city) some historical milestones of the main control measures taken between 1613 and 1917 . $[12,15,17]$

First institutions to address leprosy Until the end of the nineteenth century, there was no organized leprosy control activity in Cuba. Isolation facilities, primarily charitable institutions, were created in response to social pressure because of prejudice and stigma surrounding leprosy.[15] Patients were hospitalized and segregated. Their dermatological lesions were treated and they were given general care, but there was not much else to offer, since the epidemiological chain was unknown and there was no specific treatment. Nor was there any progress in physical or social rehabilitation.[15]

In 1938, the Leprosy Foundation was created, with ten dispensaries in the capital and provinces to provide diagnosis and treatment. $[5,17]$ Patients were treated with chaulmoogra, an oily compound derived from several plants of the family of Flacourtiaceae.[15]

In 1948, Havana was the site of the 5th International Leprosy Congress, where Latin American leprologists played a major role. The Congress accepted their proposed classification, which included two fundamental types of leprosy, tuberculoid and lepromatous, and a less-defined intermediate type, called indeterminate.[15,20-22]

Disease distribution In 1900, when statistical records of some infectious diseases began to be maintained in Cuba, 1000 leprosy patients were recorded in a population of about 1.4 million,[15] a prevalence of 7.1 per 10,000 population. In 1942, the first patient census was carried out, which identified 1900 cases, for a prevalence of 4 per 10,000 population.[15] Similar rates were maintained in later years, until the early 1960s, amidst lack of necessary conditions for effective treatment and control. 
Table 1: Leprosy control milestones in Cuban cities, 1613-1917

\begin{tabular}{|c|c|c|}
\hline City & Year & Control measures \\
\hline Havana & 1613 & Patients sent to hospitals outside Havana[12,15] \\
\hline Havana & 1615 & $\begin{array}{l}\text { Patients sent to hospitals in New Spain (or Hispaniola, } \\
\text { now Dominican Republic). This coercive measure } \\
\text { introduced Europe's stigmatization of leprosy to Cuba. } \\
{[12,15]}\end{array}$ \\
\hline Havana & 1618 & $\begin{array}{l}\text { Compulsory case notification } \\
\text { Patients banned from the city[15] }\end{array}$ \\
\hline Matanzas & 1639 & First cases reported (both city and province)[15] \\
\hline Havana & $1660-1661$ & $\begin{array}{l}\text { First leprosy isolation center in Cuba, embryo of a future } \\
\text { leprosarium. Religious volunteers cared for patients. } \\
{[15,18]}\end{array}$ \\
\hline Havana & 1662 & $\begin{array}{l}\text { Patients housed in huts in Caleta de San Juan Guillén, } \\
\text { outside the city[15] }\end{array}$ \\
\hline El Cobre & 1692 & First cases reported in Santiago del Prado mines[15] \\
\hline $\begin{array}{l}\text { Puerto Príncipe } \\
\text { (now Camagüey) }\end{array}$ & 1706 & $\begin{array}{l}\text { First cases reported (Transmission was thought to be } \\
\text { frequent before then, since between } 1706 \text { and } 1715 \\
\text { many patients were taken to barracks south of the } \\
\text { city, separate ones for white and black patients). The } \\
\text { Catholic Church provided care for the patients.[15,18] }\end{array}$ \\
\hline Santa Clara & 1770 & First case report[15] \\
\hline Havana & 1714 & $\begin{array}{l}\text { Royal Saint Lazarus Hospital founded in Caleta de Juan } \\
\text { Guillén[15] }\end{array}$ \\
\hline Camagüey & 1735 & Leprosy hospital built[15,18] \\
\hline Santa Clara & 1743 & Leprosy hospital built[15,18] \\
\hline Havana & 1798 & Royal Saint Lazarus Hospital rebuilt in same location[15] \\
\hline Havana & 1914 & Hospital moved to city outskirts[15] \\
\hline Havana & 1916 & $\begin{array}{l}\text { Patients transferred to municipality of Mariel (about } 30 \\
\text { km east of Havana), housed in deplorable conditions } \\
\text { in barracks used by Spanish government to quarantine } \\
\text { soldiers and immigrants[15] }\end{array}$ \\
\hline Havana & 1917 & $\begin{array}{l}\text { El Rincón Sanatorium built in town of same name, } \\
\text { some } 25 \mathrm{~km} \text { south of the city (still the site of a leprosy } \\
\text { hospital) }[15,18,19]\end{array}$ \\
\hline
\end{tabular}

The final assessment, carried out by specialists who would later be in charge of PNCL implementation, concluded that the census was still incomplete and that leprosy was distributed throughout all municipalities, but with leprogenic foci.[17,24,25] Fourteen municipalities had very high prevalence rates, from 7 to 16.7 per 10,000 population. Rates were highest in the eastern provinces of Oriente and Camagüey (according to the political and administrative divisions of the time). The former province of Oriente reported $36.6 \%$ of cases and two of its municipalities, Santiago de Cuba and Guantánamo, had extremely high rates of 28.6 and 29.3 per 10,000 population, respectively. [17]

Camagüey Province accounted for $14 \%$ of all cases, with the municipalities of Camagüey and Santa Cruz del Sur accounting for $51 \%$, with the highest prevalence rates: 7.4 and 11.5 per 10,000, respectively.[15,17] The old province of Havana recorded $27.2 \%$ of the country's cases, the highest prevalence in Regla Municipality, with 10.3 per 10,000 . The municipalities of Havana, Marianao and Santiago de las Vegas had $82 \%$ of Havana Province's patients.[15,17]

In the 1960s, PNCL actions focused mainly on diagnosis and treatment, with intensive case finding in areas with leprogenic foci and high prevalence. When PNCL began in 1963, prevalence was 5.3 per 10,000 population, had a plateau at 5 per 10,000 until 1968 and climbed up to

After 1959, Cuba's public health system moved away from a curative focus toward a preventive orientation; epidemiology programs were initiated and it was decided to tackle leprosy systematically. $[21,23]$

In 1961, a new census of leprosy patients was carried out, detecting 4500 cases, for a prevalence of 6.7 per 10,000 population, and the decision was made to establish a leprosy control program, the PNCL. A third census was carried out in 1962, before PNCL was established, in which 3662 cases were found, a prevalence of 5.4 per 10,000 population.[17]

The same year, a fourth census was carried out in all provinces. The highest prevalence rates were found in the (then) provinces of Camagüey and Oriente, with 9 and 7 cases per 10,000 population, respectively. After correcting some errors and omissions of previous censuses, 3835 cases were reported across Cuba. Only one of the country's 126 municipalities (Consolación del Norte, in the province of Pinar del Río) did not report any cases.
6.1 in 1969, with little variation from the previous decade (Figure 1). Increased case finding produced higher incidence rates. Figure 2 shows a clear uptick in incidence rates after 1963, which can be attributed to PNCL's increased detection capacity, an indicator of the effectiveness of the program's case finding activities.

Leprosy prevalence remained stable in the 1970s, with rates ranging roughly from 5 to 6 per 10,000 population (Figure 1). Incidence remained relatively constant with rates of 3.9 per 100,000 in 1970 and 3.6 per 100,000 in 1979, and a slight increase between 1975 and 1977 (Figure 2). These data reflect stability in PNCL activities and detection capacity.

Between 1980 and 1989, fewer new cases were detected (Figure 2 ), because of PNCL activities in previous years (reducing the pool of potential transmission sources by intensive case finding and treatment). By 1988, 5806 cases had been reported, for a prevalence of 5.6 per 10,000 population, with rates above 
the national average in the provinces of Camagüey (9) and especially in Guantánamo (18.3). Leprosy was distributed throughout all municipalities of the country, but in leprogenic foci, coinciding with foci identified in the 1962 census.[17] Guantánamo Municipality had the highest incidence rate in the country with 16.7 per 100,000 population, and 5 of its neighboring municipalities had rates ranging from 4.5 to 7.9 per 100,000 . Another area in Cuba's central-eastern region, involving parts of the provinces of Ciego de Avila, Camagüey and Las Tunas, also reported high numbers of incident cases. The highest rates were in the municipalities of Camagüey and Nuevitas, 10.6 and 9.2 per 100,000 population, respectively; another 7 bordering municipalities had rates between 4.6 and 4.9 per 100,000 .[17]

In 1988, PNCL activities were transferred to neighborhood family doctor-and-nurse offices[26] and a campaign was launched to actively search for cases of leprosy in at-risk groups, nonhousehold contacts of previously diagnosed patients, and the general population. This led to detection of leprosy in patients who already had some degree of disability by the time their disease was diagnosed. Since they clearly had had the disease for a long time, they were not considered new cases, but were counted in prevalence statistics. Implementing PNCL in the community increased its effectiveness.[25] In addition, early (preclinical) diagnosis using serological studies was introduced as of 1988.[25] Disease incidence was stabilized at lower-than-historical levels in the 1990s, with an average incidence rate of 2.3 per 100,000 population between 1995 and 2015 (Figure 2).

Systematic leprosy control: PNCL evolution In early 1962 the Undersecretariat (later Vice Ministry) of Hygiene and Epidemiology was created, the first time MINSAP had a large section in charge of these public health functions.[21,23,27] The National Conference on Leprosy Control Standards was held the same year, with participation by dermatologists, leprologists and epidemiologists, and outlined PNCL's fundamental design.[24] Among its highlights were proposals that treatment should be ambulatory and tests should be performed locally, in the foci themselves, to facilitate monitoring of household members and enable early diagnosis of secondary cases. These criteria and documents were discussed at the First National Forum on Hygiene and Epidemiology, held in Havana in September 1962, which formally established PNCL and laid out Cuba's hygiene and epidemiology strategy for the following ten years.[12,21,23,24]

PNCL has undergone modifications since its first version to keep up to date with scientific developments in leprosy surveillance and treatment. Table 2 presents a summarized chronicle of PNCL's evolution from its inception to the present, which includes the main actions and treatment.[21,24,25,28,29] Below is a critical review of PNCL's development and its influence on disease control.

First version (1962) The fundamental strategy was ambulatory treatment and local test performance in the foci themselves, to facilitate contact tracing and enable early diagnosis of secondary cases and carrier control. Patients with indeterminate and tuberculoid (nodular) forms were discharged from followup after 3 and 5 years, respectively. Patients with dimorphous (borderline leprosy, which is immunologically unstable) and lepromatous (a severe form in people with reduced cell- mediated immunity) forms were followed for life.[21,24,25] While some patients were cured, prevalence remained stable because of increasing incidence between 1963 and 1966 (Figures 1 and 2).

Second version (1972) A stricter epidemiological approach was applied, based on identification of leprogenic foci and increasingly more rigorous control. Treatment schedules were maintained as in the first version.[21,24,25] PNCL was integrated into the health system in community polyclinics[26] throughout Cuba. It evolved from a vertical program, delivered by dermatologists at leprosy hospitals and in dermatology services of clinical surgical hospitals, to a horizontal program, integrated into primary health care (similar to reforms in the National Tuberculosis Control Program).[30]

Third version (1977) The main difference in PNCL's third stage was modified treatment. Evident clinical improvement was attained in patients with inclusion of an attack phase with rifampicin and intramuscular acedapsone (Hansolar).[21,24,25] Controlled, ambulatory treatment was administered to paucibacillary patients for six months and to multibacillary patients for two years. Case finding was increased by contact examination and epidemiological

Figure 1: Leprosy prevalence in Cuba, 1960-2015

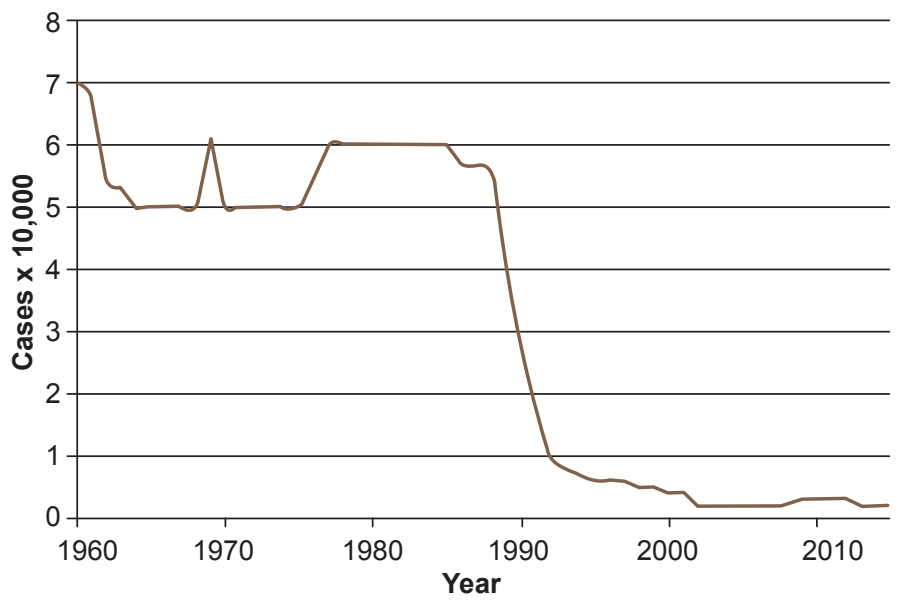

Source: National Bureau of Statistics and Medical Records, MINSAP

Figure 2: Leprosy incidence in Cuba, 1960-2015

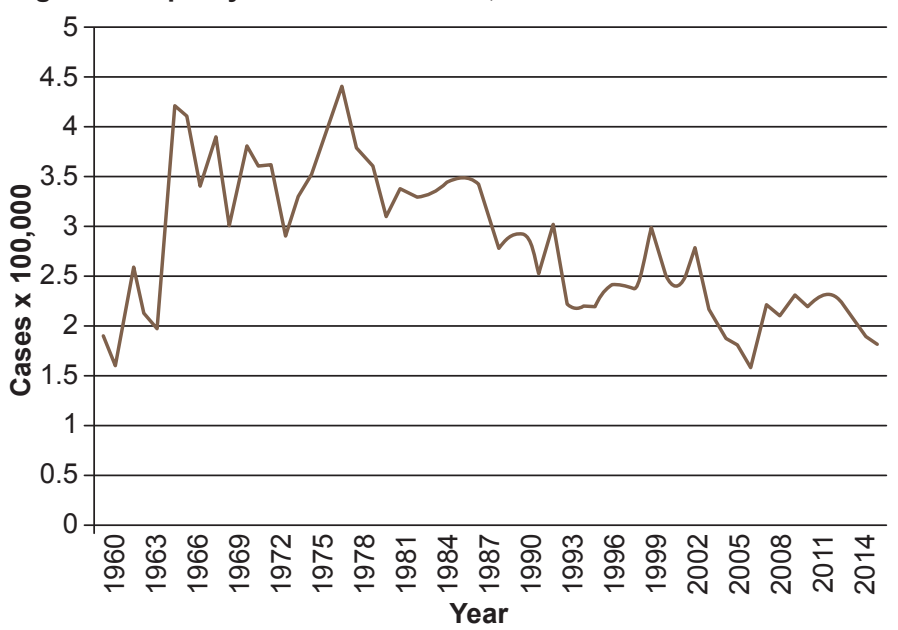

Source: National Bureau of Statistics and Medical Records, MINSAP 


\begin{tabular}{l|l|}
\hline Version & Main actions \\
\hline $1(1962)[24]$ & $\begin{array}{l}\text { Closure of most leper colonies } \\
\text { Totally ambulatory treatment } \\
\text { Patients treated in dermatology services of clinical-surgical hospitals } \\
\text { Introduction of disease cure criteria } \\
\text { Chemoprophylaxis for contacts } \\
\text { Actions aimed at early diagnosis of the disease: case finding among contacts }\end{array}$ \\
\hline $2(1972)[24,25]$ & $\begin{array}{l}\text { Decentralization of patient care; contact prophylaxis and treatment } \\
\text { transferred to polyclinics[25] } \\
\text { Closure of remaining leper colonies. Only the old leprosy hospital remained, } \\
\text { as the reference center, transformed into the Dermatology Hospital } \\
\text { Supervised drug administration and chemoprophylaxis continued } \\
\text { New epidemiological approach: determination of leprogenic foci and more } \\
\text { rigorous control with case finding in household contacts }\end{array}$
\end{tabular}

3 (1977)[21,24,25] Introduction of new drugs (rifampicin and acedapsone)

Rifampicin administration to all existing and new cases

Supervised ambulatory treatment

Case finding by examination of contacts and cohabiting family members, including second-degree relatives; active case finding in workplaces and other institutions

Treatment ${ }^{\mathrm{a}}$

Dapsone (diaminodiphenylsulfone)

Week 1: $100 \mathrm{mg}$

Week 2: $200 \mathrm{mg}$

Following 6 weeks: $300 \mathrm{mg}$

Rest two weeks and repeat

Introduction of sulfamethoxypyridoxine ${ }^{b}$

Dapsone and sulfamethoxypyridoxine

Same treatment as previously

\section{Rifampicin and acedapsone}

Attack phase: $1200 \mathrm{mg}$ rifampicin (while fasting) for 6 months in patients with positive smear microscopy

Consolidation phase: acedapsone $1.5 \mathrm{~mL}$

intramuscular injection monthly

Paucibacillary patients: 6 months

Multibacillary patients: 2 years

\begin{tabular}{l|l}
\hline 4 (1988)[25] & $\begin{array}{l}\text { Decentralization of patient care to neighborhood family doctor-and-nurse } \\
\text { offices[25] } \\
\text { Active case finding in at-risk population }{ }^{c} \text { and nonhousehold contacts (e.g. } \\
\text { coworkers or classmates) } \\
\text { Emphasis on early diagnosis: preclinical diagnosis by serology (ELISA for } \\
\text { Mycobacterium leprae) } \\
\text { Prevention of disabilities } \\
\text { Public education on leprosy curability } \\
\text { Introduction of treatment regimens specific to clinical forms } \\
\text { Shortening of paucibacillary treatment time to } 6 \text { months }\end{array}$ \\
& \\
5 (2003)[28] & $\begin{array}{l}\text { Early diagnosis by serology (ELISA and fluorescent antibody absorption test) } \\
\text { Use of other therapies, such as immune prophylaxis and immunotherapy } \\
\text { (BCG vaccination) } \\
\text { Disability prevention } \\
\text { Reduction of multibacillary treatment time to } 12 \text { months }\end{array}$
\end{tabular}
\begin{tabular}{l|l|l}
6 (2008)[29] & Early diagnosis, before irreversible injuries occur & Multibacillary (12 $\mathrm{mo}$ \\
& $\begin{array}{l}\text { Intensive contact tracing } \\
\text { 5-year followup of at-risk population }{ }^{c} \text {, with dermatological and neurological } \\
\text { examination }\end{array}$ & $\begin{array}{l}\text { First day: } \\
\text { Rifampicin } 600 \mathrm{mg} \\
\text { Clofazimine } 300 \mathrm{mg}\end{array}$ \\
\end{tabular}

Clofazimine $300 \mathrm{mg}$

Days 2-28:

Clofazimine $50 \mathrm{mg}$

Dapsone $100 \mathrm{mg}$

Paucibacillary (6 months)

First day:

Rifampicin $600 \mathrm{mg}$

Dapsone $100 \mathrm{mg}$

Days 2-28:

Dapsone $100 \mathrm{mg}$

Source: National Leprosy Control Program in Cuba, MINSAP

${ }^{a}$ All drugs given in a single oral dose daily, unless otherwise specified

${ }^{b}$ Alfredo Abreu PhD, personal communication (June 2, 2016)

'Population residing near patient household and having direct or indirect contact

ELISA: enzyme-linked immunosorbent assay

investigation in workplaces and other institutions. However, these innovations failed to achieve cure in all cases or reduce transmission, and resistant strains of bacilli appeared.[20,21] Although reservoir elimination and incidence reduction were not achieved, the new PNCL actions contributed to improving detection capacity.[20]
Fourth version (1988) This instituted controlled, decentralized, multidrug treatment with dapsone, rifampicin and clofazimine, a new bactericidal antibiotic. [25] Such decentralization became feasible at the neighborhood level through the family doctors and nurses,[26] who carried out active case finding in atrisk populations and nonhousehold contacts, with emphasis 
on early diagnosis[20,21,25] (including preclinical serological diagnosis with the enzyme-linked immunosorbent assay for $M$. leprae).[9]

This fourth version emphasized disability prevention, population health education about leprosy's curability, and introduction of treatment regimens specific to the clinical forms of leprosy. Treatment time was shortened to six months for paucibacillary and two years for multibacillary forms.[25,31,32]

Through PNCL actions, supported by organizational changes in medical services, universal health care, including primary care, and a systemic approach to major health problems, the total number of patients fell from 5638 in 1986 (prevalence 5.7 per 10,000 population) to 458 in 2002 , for a rate of 0.4 per 10,000 population (Figure 1).[31]

In 1993, when leprosy prevalence in Cuba fell to <1 per 10,000 population, it ceased to be a public health problem by WHO's definition[11] but cases still occur, including in children.[31,33]

Fifth version (2003) The program was revised because of upturns in incidence in the preceding five years, when 316 and 246 cases were reported annually (rates between 2.4 and 3 per 100,000 population) (Figure 2).[28] Greater emphasis was placed on early diagnosis and prophylactic treatment. In addition to technological innovations in diagnosis and treatment, the most striking development in this version was the reduction of treatment time to 12 months in multibacillary patients. $[9,28]$

Sixth version (2008) This version, still in effect,[29] is oriented to keeping prevalence below the elimination threshold. This postelimination phase is characterized by stabilization of prevalence due to a balance between new cases diagnosed and cured patients. Between 2004 and 2010, incidence remained stable at around 2.3 per 100,000 population. The goal of early diagnosis has been reinforced.

Leprosy diagnosis must be carried out in primary health care, based on dermatological and neurological examination by a dermatologist on referral by a family doctor when leprosy is suspected.[29,32] The specialist performs the lepromin test and orders complementary diagnostic tests, such as serology, bacilloscopy and, in some cases, PCR, for real-time diagnosis. $[29,32]$ When diagnosis is confirmed, the case is reported, epidemiological investigation carried out and treatment begun. Simultaneously, primary care focus control activities, including contact tracing are initiated.[29,31,32]

The strategy has as its main goal the identification of occult cases and early detection of new cases. It involves:

- defining a three-year transition stage to validate elimination;

- estimating prevalence of occult leprosy based on the proportion of new cases detected late (detection $>11$ months after patient-reported symptom onset, or disability);

- elaborating a new stratification according to the estimated prevalence; and

- establishing priorities for provinces, municipalities and health areas (primary care catchment areas, each served by a polyclinic with a multidisciplinary team of primary care specialists and several family doctor-and-nurse offices).[29,32]

Critical evaluation PNCL's ultimate goal is to eliminate leprosy, which in practical terms is achieved when prevalence falls to $<1$ per 10,000 population.[11] In 2012, a technical meeting in consultation with PAHO was held in Havana to determine strategies for maintaining and building on progress already made.[31]

Until 2006, it was impossible to collect data on classification of diagnosed cases by the operational criteria defined. Between 2006 and 2012, >50\% of new cases diagnosed were multibacillary, accounting for up to $84 \%$ of incidence.[31-33] In 2014, multibacillary forms were $87 \%$ of new cases in Argentina and $32.9 \%$ in the Dominican Republic.[34]

Instability and treatment adherence problems have been reported since the late 1980 s, $[35,36]$ explaining relapse rates of up to $5.3 \%$ reported between 2006 and 2013, since there were no signs of primary or secondary drug resistance (Dr. María Elena Rodríguez, personal communication, September 24, 2013).

Between 1990 and 2015, 1.6\% of new cases were among those aged <15 years.[31,33] Although work to eliminate childhood leprosy is still ongoing, in 2013 there were 11 new cases, for an incidence rate of 0.6 per 100,000 population, the highest in that time period (Figure 3).[31,33] However, fewer cases are reported than in other endemic countries. For example, in Brazil, which has a leprosy control program,[37] $7.5 \%$ of the cases diagnosed in 2014 , were in the population aged $<15$ years. [34]

In 2008 , there was a jump in late diagnosis, to $35.6 \%$ from a baseline of $25.7 \%$ in 2006 , but PNCL was able to bring it down, finishing the period at $25.1 \%$ in 2015 (with lows of $19.4 \%$ in 2010 and 2012).[31,33] An increase in late diagnosis constitutes a PNCL failure, mainly inadequate case finding,

Figure 3: Leprosy incidence in pediatric population ( $<15$ years), Cuba, 1990-2015

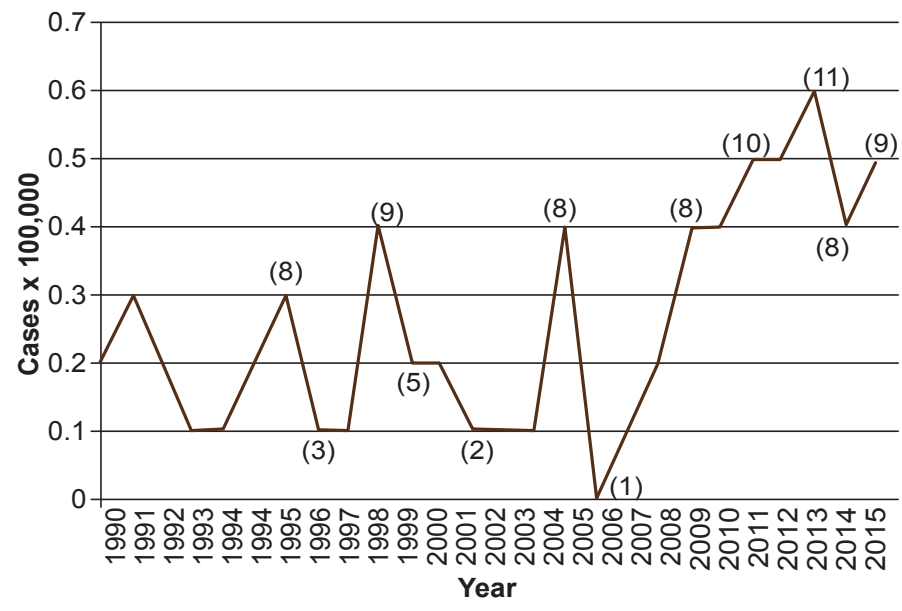

Source: National Medical Records and Health Statistics Bureau, MINSAP Note: When numbers are small, rates can vary widely from year to year, so numbers of cases are shown in parentheses for some years. 
possibly because family physicians do not actively search for cases among risk groups and overlook leprosy in their differential diagnosis because it is so rare.

To remedy this situation, emphasis should be placed on knowledge and diagnosis of leprosy among primary health care physicians; and on promoting training activities, both clinical and related to PNCL's strategies and specific measures. The proportion of late-diagnosed cases presenting with grade 2 disability increased from $3.4 \%$ in 2005 to $10.1 \%$ in 2015 (Figure 4).[31,33] In 2014, in Colombia, the proportion of newly diagnosed cases with grade 2 disability was $12.2 \%,[34]$ higher than in Cuba (8.1\%) the same year.[33]

The strategy of secondary prevention based on early diagnosis and timely treatment increases probability of cure, prevents sequelae, limits reservoirs and, in so doing, contributes to primary prevention. Furthermore, it is reflected in better quality of life and enables social reintegration and rehabilitation, as part of tertiary prevention, since leprosy is a disease that generates social exclusion.[20,32]

The majority of diagnosed leprosy cases should be detected in risk groups and contacts of already known leprosy cases and not among symptomatic patients presenting spontaneously,

Figure 4: New leprosy cases with grade 2 disability in Cuba, 2005-2015

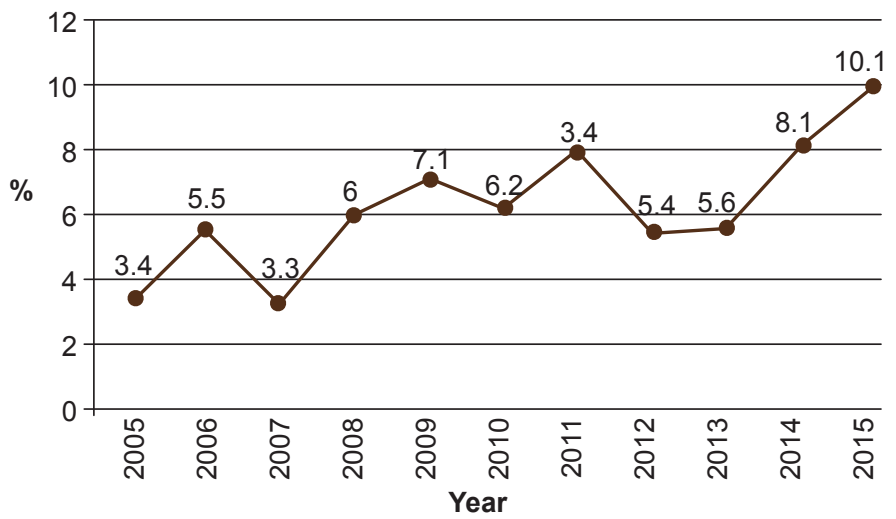

Source: Reportable Disease Declaration Cards and Epidemiologic Surveys, National Leprosy Control Program, MINSAP

Figure 5: New leprosy cases in Cuba by detection source, 2010-2015

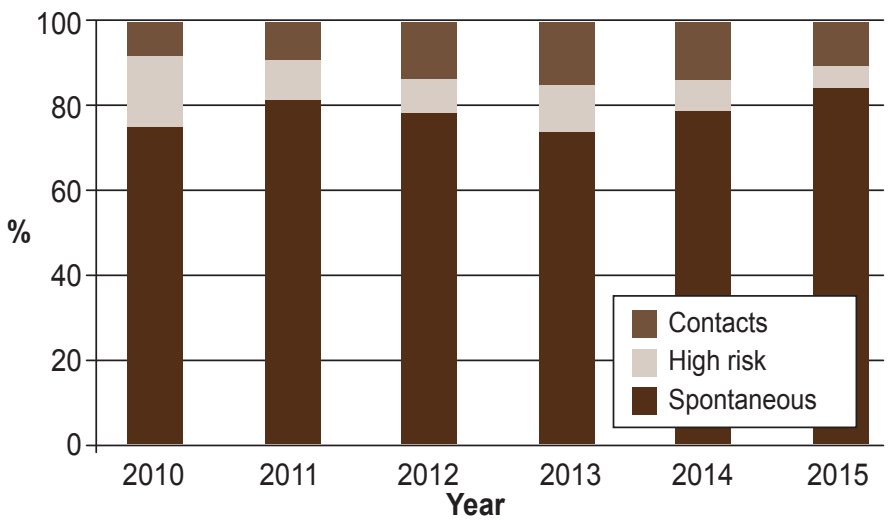

Source: Reportable Disease Declaration Cards and Epidemiological Surveys, National Leprosy Control Program, MINSAP which is what has been happening in the last six years. However, despite PNCL's activities, most diagnosed cases still arise from spontaneous consultations by symptomatic patients, accounting for $72.8 \%-84.5 \%$ of new diagnoses in $2010-2015$, Only $4.8 \%-$ $16.5 \%$ of new cases were found among the at-risk population and $8 \%-15.9 \%$ among patient contacts (Figure 5 ). This reflects deficient case finding; hence the importance of redoubling casefinding efforts.

A decline in leprosy prevalence was evident beginning in the late twentieth century. From 1988 onwards prevalence decreased steadily and stabilized at 0.2 in 2002-2015 (Figure 1), confirming elimination of leprosy as a public health problem in Cuba. $[11,31,34,37]$ This fact is directly related to advances in current leprosy treatment. Since prevalence is the product of incidence and duration, shortening duration of treatment has the effect of reducing prevalence, even when incidence remains steady. Incidence had an uneven but perceptible downward trend beginning in 1977 with 4.5 per 100,000 , reaching 1.8 per 100,000 in 2015 (Figure 2).[33]

Prevalence varied by province. The eastern provinces of Guantánamo and Granma (which had a history of leprogenic foci) reported the highest rates in 2010 , with 0.7 per 10,000 population. The lowest prevalence rates were found in the provinces of Pinar del Río, Havana, Havana City, Matanzas, Cienfuegos and Las Tunas, all with 0.1 per 10,000 population.[33] Provinces with long-standing leprogenic foci have higher prevalence, since older cases with very advanced disease, deformities and limitations, do not respond completely to treatment to achieve full cure.

Among the main actions of PNCL's strategy for the immediate future are improving the registry of suspected leprosy cases, using it to increase the case detection system's sensitivity; continuing work in the provinces with a risk approach based on stratification, reinforcing dermatological care coverage in all health areas, and intensifying contact followup and case finding in populations at risk. To do this, it is essential to revitalize the work nurse interviewers, provide training and continuing professional education in microbiological and histopathological diagnosis of leprosy for specialists in the provinces, identify patients at risk of disability, and care for those already disabled.[31,32,34]

\section{CONCLUSIONS}

Although public actions against leprosy began in Cuba in 1613, it was only after 1963 that they became systematic, within the framework of PNCL. Over the years, PNCL has been modified to stay compliant with WHO guidelines, and since 1993 it has maintained leprosy prevalence below the threshold for WHO's definition of a public health problem, although the disease has still not been eliminated. Incidence has remained stationary in recent years. Continuing detection of leprosy in the pediatric population indicates that there is household transmission, which could be prevented with intensive contact tracing and adequate chemoprophylaxis.

Late diagnosis continues to be a problem (exceeding $20 \%$ in the last ten years), with high percentages of grade 2 disability among up to $10 \%$ of patients diagnosed late. Too many cases are detected when patients are already symptomatic, rather than among 
contacts or populations at risk, pointing to a need to improve case finding in primary care. It is particularly important to educate primary care personnel on leprosy diagnosis and management, as well as PNCL's norms.

Despite these difficulties, leprosy's low incidence and prevalence demonstrate the effectiveness of PNCL's five decades of work in Cuba.

\section{ACKNOWLEDGMENTS}

Thanks to Dr Edilberto González Ochoa, head of the Pedro Kourí Tropical Medicine Institute (IPK) mycobacteria program; Dr Alfredo Abreu, head of MINSAP's National Dermatology Group; Dr María Elena Rodríguez, IPK consultant and dermatologist; Dr Nieves Atrio, head of the province of Camagüey's Leprosy Control Program; and Dr Raisa Rumbaut, PNCL director. $-1 /$ -

\section{REFERENCES}

1. Saverbrey Calap N. Enfermedades Cutáneas e Infecciones Venéreas. 3rd ed. Havana: Editorial Científico-Técnica; 1987. p. 108-15 Spanish.

2. Pastrana Fundora F, Ramírez Albajéz CR, Moredo Romo E, Ramírez Ramírez H, Alemañy Díaz-Perera C. Impacto de la lepra en la historia. Folia Dermatol Cuba [Internet]. 2012 [cited 2013 Sep 19];6(1). Available from: http://bvs.sld.cu/ revistas/fdc/vol6_1_12/fdc06112.htm. Spanish.

3. World Health Organization. Globalleprosystrategy 2016-2020: accelerating towards a leprosyfree world [Internet]. New Delhi: World Health Organization; SEARO/Department of Control of Neglected Tropical Diseases; 2016 [cited 2016 Dec 16]. 20 p. Available from: http://apps.searo .who.int/PDS DOCS/B5233.pdf

4. Palú Orozco A, Orozco González MI, Batista Duharte A, Pérez Pérez IM, García Vidal A. Principales aspectos inmunológicos en familias con casos secundarios de lepra en el área de salud "Frank País García". MEDISAN [Internet]. 2011 [cited 2013 Jan 20];15(1):50-7. Available from: http://scielo.sld.cu/scielo.php?script=sci _arttext\&pid=S1029-30192011000100007\&lng= en\&tlng=en. Spanish.

5. Carrazana Hernández GB, Ferrá Torres TM, Pila Pérez R. Estudio de las incapacidades causadas por la lepra. Rev Leprol Fontilles. 1990;17(6):547-55. Spanish.

6. Moreira Ríos I, Moreno Díaz EN, Sotolongo Castillo A, Rivera Moreira A, Carballea Suárez Y. Enfoque de los factores de riesgo de la lepra con las determinantes sociales de la salud. Rev Cubana Higiene Epidemiol. 2014;52(1):4-14. Spanish.

7. World Health Organization. WHO Expert Committee on Leprosy: Eighth Report. World Health Organization technical report series 968 (2012) [Internet]. Geneva: World Health Organization; 2012 [cited 2016 Dec 19]. 61 p. Available from: http://www.searo.who.int/entity/ global_leprosy_programme/publications/8th_ex pert comm 2012.pdf

8. World Health Organization. Multidrug therapy against leprosy: development and implementation over the past 25 years [Internet]. Geneva: World Health Organization; 2004 [cited 2016 Dec 19]. 179 p. Available from: http://www.who .int/lep/resources/MDT_Full.pdf

9. López-Antuñano FJ. Diagnóstico y tratamiento de la lepra. Salud Púb Méx [Internet]. 1998 Jan-Feb [cited 2013 Sep 1];40(1):1-10. Available from: http://www.scielo.org/pdf/spu/v40n1/ Y0400110.pdf. Spanish.

10. Idema WJ, Majer IM, Paham D, Oskam L, Polinder $\mathrm{S}$, Richardus JH. Cost-effectiveness of a chemo prophylactic intervention with single dose rifampicin in contacts of new leprosy patients. PLoS Negl Trop Dis. 2010 Nov 2;4(11):e874.

11. World Health Organization. Guía para la eliminación de la lepra como problema de salud pública. Geneva: World Health Organization; 2000. Spanish.

12. López Sánchez J. La Medicina en La Habana. Cuaderno de Historia de la Salud Pública. 1970;47. Spanish.
13. Hernández Sampieri R, Fernández Collado C, Baptista Lucio P. Metodología de la Investigación. Bogotá: McGraw Hill; 1996. Spanish.

14. Díaz Almeida JG. Lepra. In: Manzur Katrib J, Díaz Almeida JG, Cortés Hernández M, editors. Dermatología. Havana: Editorial Ciencias Médicas; 2002. p. 200-23. Spanish.

15. González Prendes MA. Historia de la lepra en Cuba. Havana: Publicaciones del Museo Histórico de las Ciencias Médicas; 1963. Spanish.

16. Población de Cuba según censos [Internet]. Havana: National Statistics Bureau (CU); 2010 [cited 2013 Sep 1]; [about 6 screens]. Available at: https://www.ecured.cu/ Anexo:Poblaci\%C3\%B3n_de_Cuba. Spanish.

17. Íñiguez L, Rodríguez Fleitas C, Palacín A. Geografía de la lepra en Cuba. Havana: University of Havana; 1994. Spanish.

18. Torres Cuevas E, Leiva Lajara E. Historia de la Iglesia Católica en Cuba. La iglesia en las patrias de los criollos (1516-1789). Havana: Ediciones Boloña; 2008. 479 p. Spanish.

19. Bernal Alonso, Eduardo M. Rincón y la peregrinación de San Lázaro. Raíces de una centenaria tradición cubana. Havana: Editorial José Martí; 2011. 156 p. Spanish.

20. Rivero Reyes E, Barrios Martínez Z, Berdasquera Corcho D, Tápanes Fernández T, Peñalver Sinchay AG. La lepra, un problema de salud global. Rev Cubana Med Gen Integr [Internet]. 2009 JanMar [cited 2012 Dec 12];25(1). Available from: http://scielo.sld.cu/scielo.php?script=sci_arttext\&p id=S0864-21252009000100010. Spanish.

21. Del Puerto C, Ferrer H, Toledo G. Higiene y epidemiología, apuntes para su historia. Havana: Editorial Palacio de las Convenciones; 2002. p. 186-7. Spanish.

22. Pardo Castelló V. Dermatología y sifilografía. Havana: Ediciones Cultural S.A.; 1953. Spanish.

23. Beldarraín Chaple E. Apuntes sobre la medicina en Cuba. Historia y publicaciones. Havana: Editorial Ciencias Médicas; c2005. Chapter 6, Historia y Publicaciones. Spanish.

24. Abreu A, Werthein L, Ruiz de Zárate S, Ayvado A. El programa de control de lepra en Cuba. Estado actual. Bol Higiene Epidemiol. 1976;14(2):11722. Spanish.

25. Ministry of Public Health (CU). Programa de control de la lepra. Havana: Editorial Ciencias Médicas; 1988. Spanish.

26. Luna Morales EC, Sierra Pérez DC, Gandul Salabarría L. La transformación del policlínico en Cuba de cara al siglo XXI. Rev Cubana Med Gen Integr. 2009 Jul-Sep [cited 2015 Sep 2];25(2). Available from: http://scielo.sld.cu/scielo.php?script=sci_art text\&pid=S0864-1252009000200016\&lng=es\&nr $\mathrm{m}=\mathrm{iso} \&$ tlng=es. Spanish.

27. Delgado G. Conferencias de historia de la administración de Salud Pública en Cuba. Cuaderno de Historia de la Salud Pública. 1991;81. Spanish.

28. Ministry of Public Health (CU). Programa de control de la lepra. Havana: Editorial Ciencias Médicas; 2003. Spanish.

29. Ministry of Public Health (CU). Programa de control de la lepra. Havana: Editorial Ciencias Médicas; 2008. Spanish.
30. Beldarraín Chaple E. Impact of the 1970 Reforms to Cuba's National Tuberculosis Control Program. MEDICC Rev. 2015 Jul;17(3):33-8.

31. Rumbaut Castillo R. Situación epidemiológica de la lepra en Cuba. Programa Nacional de Control de la Lepra. Presentation at the PAHO Expert Committee on Leprosy Meeting; 2012; Havana, Cuba. Havana: [publisher unknown]; 2012. Spanish.

32. Ministry of Public Health (CU). Lepra. Normas técnicas para el control y tratamiento. Havana: Editorial Ciencias Médicas; 2008. Spanish.

33. National Health Statistics and Medical Records Division (CU). Anuario Estadístico de Salud 2015. Havana: Ministry of Public Health (CU); 2016. 208 p. Spanish.

34. World Health Organization. Global leprosy update, 2013; reducing disease burden. Weekly Epidemiological Record (WER) [Internet]. 2014 Sep 5 [cited 2015 Sep 2];89(36):389-400. Available from: http://www.who.int/wer. English, French.

35. Olivares Sabournin R, González Segredo AB. Estudio bacteriológico en pacientes con lepra multibacilar tratados con rifampicina y acedapsone. Rev Cubana Med Trop. 1989 MayAug:41(2):307-12. Spanish.

36. González Segredo AB, González Abreu Castells E, Valdés Portela Rodríguez A, Suárez Moreno O, Olivares Sabournin R. Lepra: una breve síntesis del tema. Rev Cubana Med Trop. 1988 MayAug;40(2):67-81. Spanish.

37. Pan American Health Organization. Plan de acción para acelerar el logro de la eliminación de la lepra en Latinoamérica y el Caribe [Internet]. Washington, D.C.: Pan American Health Organization; 2011 [cited 2015 Mar 15]. Available from: http://www.paho.org/hq/index.php?option=com docman\&task=doc_view\&gid=26612\&Itemid. Spanish.

\section{THE AUTHOR}

Enrique Beldarraín-Chaple (ebch@infomed. sld.cu), epidemiologist with a doctorate in health sciences. Full professor at the Medical University of Havana; senior researcher and research director, Cuban National Health Care Telecommunications Network and Portal, Havana, Cuba.

Submitted: September 3, 2015

Approved for publication: December 2, 2016 Disclosures: None 